\title{
Another World? East Africa, Decolonisation, and the Global History of the Mid-Twentieth Century
}

\author{
Ismay Milford (D), Gerard McCann, Emma Hunter and Daniel Branch \\ The University of Edinburgh, University of York, The University of Edinburgh and University of Warwick
}

\begin{abstract}
This article proposes that there is a gap in our current understanding of the globalising and deglobalising dynamics of mid-twentieth-century East Africa, one that might be addressed by consolidating and taking forward recent developments in the historiography of decolonisation. Recent work by international historians has recovered the connected world of the 1940s to 1960s: the era of new postcolonial states, the 'Bandung moment', pan-African cooperation, and the early Cold War. Yet East Africa is less prominent in these histories than we might expect, despite the vibrancy of current work on this period in Kenya, Uganda, and Tanzania. Bringing these two fields into dialogue, through an explicitly regional East African framework and with a particular focus on individual lives, expands our understanding not only of the 'globalisation of decolonisation' but also of the deglobalising dynamics of the following decades that are frequently reduced to a history of global economic crisis.
\end{abstract}

Keywords: Kenya; Uganda; Tanzania; East Africa; biography; decolonisation; global; historiography

Written from a world that appears to be deglobalising, this article revisits a period in which global connections proved to be both powerful and fragile. Our focus is the mid-twentieth century, the period from roughly the 1940 s to the 1970s, viewed from East Africa. It was a time, the then-Makerere student Ngũgĩ wa Thiong'o writes, when 'the impossible seemed possible'. The era of decolonisation opened up new forms of political community and new terms of engagement with the wider world; it was not merely a new stage in a history of external dominance indistinct from the colonialism that preceded it or the marginalisation that followed in the age of global markets and capital. ${ }^{2}$

A growing body of work by international historians recovers the connected world(s) of the first part of this period, from the 1940s to the early 1960s, which saw the birth of new postcolonial states, the 'Bandung moment', pan-African cooperation, and the early Cold War. Exciting new scholarship traces the networks of solidarities, built through personal connections as well as through print, which bonded individuals, communities, and organisations across oceans and continents. ${ }^{3}$ As the Afro-Asian Networks Research Collective writes, this was 'not just an era of postcolonial diplomacy,

\footnotetext{
${ }^{1}$ N. Thiong'o, Birth of a Dreamweaver: A Writer's Awakening (London, 2016), 222.

${ }^{2}$ A. Olukoshi, T. Hormeku-Ajei, A. Balaji, and A. Nayar, 'Reclaiming Africa's early post-independence history', Africa Is A Country, 202), https://africasacountry.com/2020/07/reclaiming-africas-early-post-independence-history, accessed 13 Oct. 2020.

${ }^{3}$ C. J. Lee, Making a World after Empire: The Bandung Moment and Its Political Afterlives (Athens, OH, 2010); J. J. Byrne, Mecca of Revolution: Algeria, Decolonization, and the Third World Order (Oxford, 2016); M. Louro, C. Stolte, H. Streets-Salter, and S. Tannoury-Karam (eds.), The League Against Imperialism: Lives and Afterlives (Leiden, 2020); contributions to the special issue 'Other Bandungs', Journal of World History, 30:1-2 (2019); Contributions to the special issue 'Trade union networks and the politics of expertise in an age of Afro-Asian solidarity', Journal of Social History, 53:2 (2019); I. Milford, 'Harnessing the wind: East and Central African activists and anticolonial cultures in a decolonising world, 195264' (unpublished PhD thesis, European University Institute, 2019).

(C) The Author(s), 2021. Published by Cambridge University Press. This is an Open Access article, distributed under the terms of the Creative Commons Attribution licence (http://creativecommons.org/licenses/by/4.0/), which permits unrestricted re-use, distribution and reproduction, provided the original article is properly cited.
} 
but a period of intensive social and cultural interaction across the decolonizing world' as 'African and Asian women, socialists, communists, trade unionists, intellectuals, activists and revolutionaries conversed' and imagined new and different futures 'across national, linguistic, and ideological borders'. ${ }^{4}$ Nor was this effort solely one of the radical left; networks of non- and anticommunists were just as influential. ${ }^{5}$ If decolonisation was 'globalising', inasmuch as it went hand in hand with the building of international and transnational connections, then we are beginning to understand the processes and individuals that made it so. ${ }^{6}$

East Africa, and East Africans, have been less prominent in these new connected histories of decolonisation than are other world regions and peoples. This, we suggest, is the result not of a less connected history, but of historiographical developments which themselves grew out of the specific postindependence contexts of East African nations. As we explain below, however, an emerging body of scholarship on East Africa during this period demonstrates that an attentiveness to global connections need not come at the cost of 'deep-rooted' histories of the region.

In this article we ask what bringing new histories of East Africa into dialogue with recent international histories of decolonisation might tell us about globalising and deglobalising dynamics in mid-twentieth-century East Africa - and indeed about the fragile nature of global connections more broadly. As we know, the connected worlds of the decolonisation era, and the associated sense of excitement that such connections provoked among those who lived through it, proved to be fleeting. ${ }^{7}$ Many connections in social, cultural, and intellectual spheres that had defined the process of decolonisation faltered; visions for a radically different postcolonial world proved untenable. These are the dynamics - neither absolute nor uniform - that we describe here as deglobalising.

Such dynamics, we contend, cannot be fully captured by retrospective narratives of global economic crisis and the inherent structural failures of postcolonial nation-states. It is for this reason that it may be productive to think about the 1940s to the 1970s in terms of global connections. If historians' understanding of the globalising dynamics of the years immediately before and after independence has been expanded by looking beyond the state, then the same is likely to be true when studying deglobalising dynamics. The first half of this article sets the historiographical scene for this intervention, explaining why we argue for a consciously regional East African framing and a focus on individual lives which shows the conditions in which these global connections fractured. The second half asks what this might look like by exploring various types of global connection and their limits across the period through a series of thematic case studies.

\section{Part I: Histories of East Africa and East African global histories Power of national historiographies}

While studies of East Africa's environmental, cultural, social, and economic history have long been transnational and global in scope, historical research on the region's varied experiences of decolonisation remains commonly segmented by territorial nation-states. Furthermore, the historiographies of decolonisation in each East African state have developed their own modes of framing: kingdoms and the emergence of military rule in Uganda, ethnicity and the Mau Mau rebellion in Kenya, the nation and party in mainland Tanzania, the 1964 revolution and the preceding violent electoral

\footnotetext{
${ }^{4}$ Afro-Asian Networks Research Collective, 'Manifesto: networks of decolonization in Asia and Africa', Radical History Review, 131 (2018), 176.

${ }^{5}$ A. Carew, 'Conflict within the ICFTU: anti-communism and anti-colonialism in the 1950s', International Review of Social History, 41:2 (1996), 147-81; S. L. Lewis, “We are not copyists": socialist networks and non-alignment from below in A. Philip Randolph's Asian journey', Journal of Social History, 53:2 (2019), 402-28.

${ }^{6} \mathrm{M}$. Thomas and A. Thompson, 'Rethinking decolonization: a new research agenda for the twenty-first century', in M. Thomas and A. Thompson (eds.), The Oxford Handbook of the Ends of Empire (Oxford, 2018), 1-22.

${ }^{7}$ J. Allman, 'The fate of all of us: African counterrevolutions and the ends of 1968', The American Historical Review, 123 (2018), 728-32.
} 
politics in Zanzibar. ${ }^{8}$ The result is that the historiography risks overemphasising the differences between decolonisation in these three countries and overlooking the insights that come from posing the same questions to each. To take one example, the new 'political tribalisms' that were famously forged in late colonial Kenya were also being forged in late colonial mainland Tanzania, but the latter have received less attention from historians and not solely because ethnic divisions played a less central role in the workings of the early postcolony. ${ }^{9}$

Historians of Kenya, Uganda, and Tanzania are well aware of - and increasingly reflect upon the trappings of the respective national historiographies that grew around particular themes during the intertwined processes of establishing new nations and institutionalising the discipline of African history in each country from the 1960s onwards. This conscious deconstruction of nation and nationalism has produced highly innovative and influential scholarship on East African decolonisation, particularly through explorations of popular and textual cultures, gender and sexuality, and youth, often engaging explicitly with the field of global cultural history. ${ }^{10}$ The city has been one important mode of framing such histories. ${ }^{11}$ However, even where work is undertaken on cross-cutting themes, for example development, studies often remain within the boundaries of particular nation-states. ${ }^{12}$ And as Gregory Maddox has recently emphasised in relation to Tanzania, even where historians set out to challenge the national framework, the concerns of national historiographies - in Tanzania's case concern with nation and party - can continue to shape their scholarship. ${ }^{13}$

One way in which a growing number of historians are breaking out of national containers is through a regional approach. In his 1994 call for new histories of the late colonial period, Frederick Cooper wrote that "politics in a colony should not be reduced to anticolonial politics or to nationalism: the "imagined communities" Africans saw were both smaller and bigger than the nation, sometimes in creative tension with each other, sometimes in repressive antagonism. ${ }^{14}$ Recognising this has allowed historians to rethink the geographical scope of their research. A growing body of East Africanist work crosses national territories to think about how ideas of community were formed, political boundaries were contested and created, and how sovereignty was subsequently experienced by those who found themselves minorities in new states. ${ }^{15}$ Others have

\footnotetext{
${ }^{8}$ For further discussion, see O. Masebo, 'New thematic directions in history at the University of Dar Es Salaam', Tanzania Zamani, 9:2 (2017), 1-67; B. A. Ogot, 'Mau Mau and nationhood: the untold story', in E. S. Atieno Odhiambo and J. Lonsdale (eds.), Mau Mau and Nationhood: Arms, Authority and Narration (Oxford, 2003), 8-36; D. Peterson and E. Taylor, 'Rethinking the state in Idi Amin's Uganda: the politics of exhortation', Journal of Eastern African Studies, 7:1 (2013), 58-63.

${ }^{9} \mathrm{G}$. Maddox and J. Giblin, In Search of a Nation: Histories of Authority and Dissidence in Twentieth-Century Tanzania (Oxford, 2005); J. Lonsdale, 'Moral ethnicity and political tribalism', in P. Kaarsholm and J. Hultin (eds.), Inventions and Boundaries: Historical and Anthropological Approaches to the Study of Ethnicity and Nationalism (Roskilde, 1994), 131-50.

${ }^{10}$ With particular reference to global history, see A. Ivaska, Cultured States: Youth, Gender, and Modern Style in 1960s Dar Es Salaam (Durham, NC, 2011); Laura Fair, Reel Pleasures: Cinema Audiences and Entrepreneurs in Twentieth-Century Urban Tanzania (Athens, OH, 2018); T. Burgess, 'Cinema, bell bottoms, and miniskirts: struggles over youth and citizenship in revolutionary Zanzibar', The International Journal of African Historical Studies, 35:2-3 (2002), 287-313.

${ }^{11}$ E. Callaci, Street Archives and City Life: Popular Intellectuals in Postcolonial Tanzania (Durham, NC, 2017); L. White, The Comforts of Home: Prostitution in Colonial Nairobi (Chicago, 2009); F. Cooper, On the African Waterfront: Urban Disorder and the Transformation of Work in Colonial Mombasa (New Haven, 1987).

${ }^{12}$ Two excellent recent monographs dealing with development in Tanzania and Kenya respectively are P. Lal, African Socialism in Postcolonial Tanzania: Between the Village and the World (Cambridge, 2015); K. Moskowitz, Seeing Like a Citizen: Decolonization, Development, and the Making of Kenya, 1945-1980 (Athens, OH, 2019).

${ }^{13}$ G. H. Maddox, 'The Dar es Salaam school of African history', Oxford Research Encyclopedia of African History (2018). Important examples deconstructing 'the nation' in Tanzania are J. R. Brennan, Taifa: Making Nation and Race in Urban Tanzania (Athens, OH, 2012); and Callaci, Street Archives.

${ }^{14}$ F. Cooper, 'Conflict and connection: rethinking colonial African history', The American Historical Review, 99:5 (1994), 1519.

${ }^{15} \mathrm{~J}$. MacArthur, 'Decolonizing sovereignty: states of exception along the Kenya-Somali frontier', American Historical Review, 124:1 (2019), 108-43; K. Weitzberg, We Do Not Have Borders: Greater Somalia and the Predicaments of Belonging in Kenya (Athens, OH, 2017).
} 
returned to the projects of regional integration which characterised the 1960s, articulated first in terms of the doomed East African Federation, then in the less ambitious form of the East African Community. ${ }^{16}$

Such a regional, as opposed to national (or subnational), framing allows us to recognise parallels across the region. This does not mean taking for granted the coherence of an 'East Africa' encompassing Kenya, Tanzania and Uganda: rather, it means taking seriously the region as described by a range of East African actors operating in the political and public spheres during the period of decolonisation. ${ }^{17}$ Definitions of East Africa were always contested, especially from places at the region's 'edges'. 18

Employing this East African regional frame also allows us to address an unintended consequence of the 'imagined communities' approach to the recent scholarship on decolonisation: an emphasis on 'communities' that can obscure histories of processes, groups, and individuals that exist wholly or in part outside such categorisations, or cut across them, as many did. ${ }^{19}$ Historians of South Asians in East Africa, for example, have captured the significance of lives that are otherwise largely ignored in work on 1940s and 1950s anti-imperialism, given fractious Afro-Asian relations in East Africa, such as that of G.L. Vidyarthi, editor of the prominent Nairobi-based anticolonial newspaper The Colonial Times and the first Kenyan South Asian tried for sedition. ${ }^{20}$

Enabled by the strength of scholarship that has 'deconstructed' East Africa's nations and their borders in the last decade, there is, we contend, scope for going further in demonstrating the significance of the region during the mid-twentieth century for understanding processes where the nature of global connections change over time - to explore both globalising and deglobalising processes. In this endeavour, we turn now to new trends in international and global history.

\section{Global history from East Africa and East Africa in global histories}

Recent international histories of the era of new postcolonial states, the 'Bandung moment', pan-African cooperation, and the early Cold War have shown the extent to which the mid-twentieth century world was a connected world. We can now see far more clearly than was once possible the ways in which the ideas of this period were exchanged across seas and oceans, as well as across land borders, in the period of decolonisation. ${ }^{21}$ Yet East Africa is not as prominent in such histories as we might expect.

One reason for this is structural. Much of the recent interest in decolonisation and global connections is concentrated outside East Africa, notably in the European and North American academy. Hostile visa regimes, costs of travel, and a host of other challenges have resulted in significant injustices and barriers to the engagement of Africa-based scholars with globalist academic agendas. ${ }^{22}$ These dynamics are amplified when tracing global connections that appear in

\footnotetext{
${ }^{16} \mathrm{C}$. Vaughan, 'The politics of regionalism and federation in East Africa, 1958-1964', The Historical Journal, 62:2 (2019), 519-40; K. Donovan, 'Federal futures in the times of decolonization' (conference paper, East Africa Regional Integration in Historical and Contemporary Perspective, British Institute in Eastern Africa, Nairobi, 29 July 2017).

${ }^{17}$ E. Hunter, J. MacArthur, G. McCann, and C. Vaughan, 'Thinking East African: debating federation and regionalism, 1960-1977', in F. Gerits and M. Grilli (eds.), Visions of African Unity: New Perspectives on the History of Pan-Africanism and Unification Projects (Basingstoke, 2020), 49-70.

${ }^{18}$ I. Milford, 'Federation, partnership, and the chronologies of space in 1950s East and Central Africa', Historical Journal, 63:5 (2020), 1325-48; J. Prestholdt, 'Locating the Indian Ocean: notes on the postcolonial reconstitution of space', Journal of Eastern African Studies, 9:3 (2015), 440-67.

${ }^{19}$ M. Larmer and B. Lecocq, 'Historicizing nationalism in Africa', Nations and Nationalism, 24:4 (2018), 893-917.

${ }^{20}$ S. Aiyar, Indians in Kenya: The Politics of Diaspora (Cambridge, MA, 2015), 143-9. See also R. Gregory, Quest for Equality: Asian Politics in East Africa, 1900-1967 (Hyderabad, 1993).

${ }^{21}$ S. S. Amrith, Crossing the Bay of Bengal: The Furies of Nature and the Fortunes of Migrants (Cambridge, 2013).

${ }^{22}$ All-Party Parliamentary Group (AAPG) for Africa, AAPG for Diaspora, Development and Migration and AAPG for Malawi, Visa Problems for African Visitors to the UK (London, 2019). See also contributions to the special issue introduced
} 
(sometimes recently opened) archival collections across several continents. The fact that the authors of this paper enjoy the privileges that come from employment at wealthy, Western universities is not incidental.

But beyond these structural questions, there are important intellectual reasons for the relative marginality of East African historical actors in new international histories of this period. One is that historians exploring global connections in the mid-twentieth century often look outwards from spaces already established as being globally connected. Thus, for example, while the canon of anticolonial thought from the Black Atlantic world receives increasingly rigorous scholarly attention, far less attention is given to exploring the political ideas of East Africa in this period beyond national spaces and nationalist thought. ${ }^{23}$

Related to this is a question of language. While thinkers from across the African continent contributed to Anglophone, Francophone, or Lusophone literary spheres, publishing in Indian Ocean lingua francas such as Swahili or Arabic has made a section of East African thinkers less immediately visible to global historians, particularly to Western scholars. More broadly, as recent critiques of global history have emphasised, global histories have often privileged ocean- and continent-crossing elites at the expense of the many more people who did not move, but who were nevertheless connected to a wider world through print and other media. ${ }^{24}$ Most mid-twentieth century East Africans were not members of internationally mobile elites, but many did write about and consume worlds beyond in a multilingual world of print: their words need to be carefully explored, and the importance of African-language newspapers, pamphlets, and archives in particular appreciated. ${ }^{25}$

The Indian Ocean has long played an important role in understanding global connections from East Africa, often with diasporic 'Greater Indias' set as drivers of connection up until the midtwentieth century. The recent resurgence of interest in oceanic histories has, in general, served East Africa well. ${ }^{26}$ However, histories of the Indian Ocean have only very recently extended into the period of decolonisation and even then rarely go far beyond the East African littoral. ${ }^{27}$ But the Indian Ocean's historical networks continued to shape East Africa's engagement with the rest of the world throughout the twentieth century, a dynamic visible not only in episodes like the 1964 Zanzibar Revolution but also in Nairobi's anticolonial struggles of the $1950 \mathrm{~s}^{28}$

by C. Coetzee, 'Ethical?! Collaboration?! Keywords for our contradictory times', Journal of African Cultural Studies, 31:3 (2019).

${ }^{23}$ C. Anderson, Bourgeois Radicals: The NAACP and the Struggle for Colonial Liberation (Cambridge, 2014); L. James, George Padmore and Decolonization from Below: Pan-Africanism, the Cold War, and the End of Empire (Basingstoke, 2014); J. Munro, The Anti-Colonial Front: The African American Freedom Struggle and Global Decolonization, 1945-1960 (Cambridge, 2017); B. G. Plummer, In Search of Power: African Americans in the Era of Decolonization, 1956-1974 (Cambridge, 2013); G. Wilder, Freedom Time: Negritude, Decolonization, and the Future of the World (Durham, NC, 2015).

${ }^{24}$ E. Hunter, Political Thought and the Public Sphere in Tanzania: Freedom, Democracy and Citizenship in the Era of Decolonization (Cambridge, 2015); J. Adelman, 'What is global history now?', Aeon, 2 Mar. 2017; R. Drayton and D. Motadel, 'Discussion: the futures of global history', Journal of Global History, 13:1 (2018), 1-21.

${ }^{25}$ As demonstrated, for example, in W. Muoria-Sal, B. F. Frederiksen, J. Lonsdale, and D. R. Peterson (eds.), Writing for Kenya: The Life and Works of Henry Muoria (Leiden, 2009). See also Hunter, MacArthur, McCann, and Vaughan, 'Thinking East African'.

${ }^{26}$ A. Sheriff, Dhow Cultures and the Indian Ocean: Cosmopolitanism, Commerce and Islam (Oxford, 2010); G. Desai, Commerce with the Universe: Africa, India and the Afrasian Imagination (New York, 2013); G. Campbell, Africa and the Indian Ocean World from Early Times to Circa 1900 (Cambridge, 2019); S. Bose, A Hundred Horizons: The Indian Ocean in the Age of Global Empire (Cambridge, MA, 2009; N. Green, 'Africa in Indian ink: Urdu articulations of Indian settlement in East Africa', The Journal of African History, 53: 2 (2012), 131-50; F. A. Bishara, A Sea of Debt: Law and Economic Life In The Western Indian Ocean, 1780-1950 (Cambridge, 2017).

${ }^{27}$ An example to the contrary, where this point is also noted, is F. Becker, 'Cosmopolitanism beyond the towns: rural-urban relations in the history of the southern Swahili coast in the twentieth century', in E. Simpson and K. Kresse (eds.), Struggling with History: Islam and Cosmopolitanism in the Western Indian Ocean (London, 2007), 261-90.

${ }^{28}$ M. Singh, History of Kenya's Trade Union Movement to 1952 (Nairobi, 1969); M. Singh, 1952-56 The Crucial Years of Kenya Trade Unions (Nairobi, 1980); J. Glassman, War of Words, War of Stones: Racial Thought and Violence in Colonial Zanzibar (Bloomington, IN, 2010); S. Aiyar, Indians in Kenya. 
Another factor shaping the forms of global history written from East Africa has been a lack of articulation between traditions of global history writing focused on the economy and those traditions of international and global history writing focused on politics and ideas. A key strand in global history writing from East Africa from the 1960s lay in a concern with East Africa's position within the global economy and a desire to explain the roots of a deeply unequal world. ${ }^{29}$ The University of Dar es Salaam was a hub of radical leftist thought and activism, and its scholars produced an important body of research exploring why, in spite of national independence, East Africa's place in the global economy remained marginal. If the University's history department was home to historians pioneering the new traditions of national historical writing noted above, it was also home to Walter Rodney, author of, among other important works, the powerfully argued and hugely influential book How Europe Underdeveloped Africa. ${ }^{30}$ For Rodney, this question could not be answered solely from within Africa, but rather by exploring 'the relationship between Africa and certain developed countries and ... recognizing that it is a relationship of exploitation'. ${ }^{31}$

While early accounts focused on economic drivers from outside the region and external forces that appeared to be acting on East Africa, Jeremy Prestholdt and others have shown in recent work on nineteenth-century East Africa that the much-reduced room for manoeuvre which East African economic actors experienced in the later nineteenth century - and which lasted into the twentieth - was not typical of the nineteenth century as a whole, when the decisions of individual East African consumers were able to shape global processes and flows. ${ }^{32}$ This same recognition of economic agency is visible in recent anthropological accounts of responses to structural adjustment across Africa since the 1980s and helpfully directs our attention to East African actors in the global economy. ${ }^{33}$

Attention to how individuals interacted with and shaped global structures can extend beyond the economic sphere and into the chronological gap of the mid-twentieth century. There is much more to be said about the social, cultural, and political - not only economic - engagements of East Africans with the wider world, particularly for the era of decolonisation with which we are concerned, when it seemed possible to at least imagine new structural economic relationships beyond the restrictions of colonialism, and when the opportunities for social, cultural, and political engagement across borders dramatically increased before closing down again. ${ }^{34}$

Indeed, historians of East Africa are becoming increasingly attentive to decolonisation's global connections and their limits precisely because the subjects of their research - East African citizens of the mid-twentieth century - were themselves occupied with these same connections. One research area where the excavation of East Africa's global connections during the era of decolonisation has successfully attended to both the specificities of the region and the agency of East African political actors is the Cold War. ${ }^{35}$ Africa's Cold War was initially understood through settings where

\footnotetext{
${ }^{29}$ O. Gueye, 'African history and global history: revisiting paradigms' in S. Beckert and D. Sachsenmeier (eds.), Global History, Globally: Research and Practice around the World (London, 2018), 96.

${ }^{30}$ I. Shivji, Intellectuals at the Hill: Essays and Talks 1969-1993 (Dar es Salaam, 1993).

${ }^{31}$ W. Rodney, How Europe Underdeveloped Africa (London, 2018 [1972]), 26. See also S. Amin, G. Arrighi, A. G. Frank, and I. Wallerstein, Dynamics of Global Crisis (London, 1982); J.-F Bayart, L'État en Afrique: La politique du ventre (Paris, 1989); J. Ferguson, Global Shadows: Africa in the Neoliberal World Order (Durham, NC, 2006).

${ }^{32}$ J. Prestholdt, Domesticating the World: African Consumerism and the Genealogies of Globalization (Berkeley, 2008).

${ }^{33}$ C. Piot, Remotely Global: Village Modernity in West Africa (Chicago, 1999).

${ }^{34} \mathrm{~A}$ similar argument has recently been made for the Sahara; see B. Lecocq, 'Distant shores: a historiographic view on the Sahel Sahara divide', The Journal of African History, 56:1 (2015), 23-36.

${ }^{35}$ G. Roberts, 'Politics, decolonisation, and the Cold War in Dar Es Salaam c. 1965-72' (unpublished PhD thesis, University of Warwick, 2016); J. Monson, Africa's Freedom Railway: How a Chinese Development Project Changed Lives and Livelihoods in Tanzania (Bloomington, 2009); J. Y. Sun, "Now the cry was communism": the Cold War and Kenya's relations with China, 1964-70', Cold War History, 20:1 (2020), 39-58; I. Milford, 'More than a Cold War scholarship: East-Central African anticolonial activists, the International Union of Socialist Youth, and the evasion of the colonial state (1955-65)', Stichproben - Vienna Journal of African Studies, 34 (2018), 19-43.
} 
the conflict 'turned hot', such as Lusophone Africa and the Congo, but attention is now turning to countries such as Kenya where diplomatic Cold War jockeying provided accumulative opportunities for elite politicians and their nonelite supporters. ${ }^{36} \mathrm{New}$ transnational histories of socialism centre the important connections between East Africans and the countries of the Eastern bloc, for example, with a growing literature on students abroad in particular. ${ }^{37}$ Similarly, transnational historical approaches to the civil rights movement and transatlantic pan-African networks lead to influential studies of the intimacies between African-American and East African political actors. ${ }^{38}$ Attentive to the risk of fitting these African histories into Cold War frameworks devised largely by historians of international relations, this scholarship collectively demonstrates that East African actors shaped the social, cultural, and intellectual networks they participated in. This can be taken further: an increased willingness of regional specialists of other parts of the continent to put their work into dialogue with the field of international history has produced scholarship read far beyond the field of African history. ${ }^{39}$

\section{Globalisation and deglobalisation}

There is, we contend, a gap in our understanding of what happened in mid-twentieth century Africa. The twentieth century witnessed important shifts in how global connections were limited and concomitant practices adopted. Although the colonialism practised in East Africa in the first half of the twentieth century did not necessarily reduce flows of migration around the region, it certainly channelled and controlled subjects' mobility to an unprecedented extent to serve the labour demands of colonial economies. Moreover, colonialism inhibited the ability of East Africans to engage with the world on their own terms through exchanges of objects and ideas, even as they pursued new connections, through churches for example. ${ }^{40}$ In the changed post- 1945 world, East Africans were increasingly in a position to challenge the colonial horizons imposed upon them. They seized opportunities created by the emergence of new infrastructures such as the postal service and air travel, regional and international institutions, and the growth of lingua francas. Recognising the potency of global vistas and ambitions is to recapture lost categories of understanding generated by East African citizens in the era of decolonisation. East Africans believed that their anticolonialism and their engagement with the world beyond empire would not simply lead to the creation of new nation-states, but also remake global political and economic structures. Kenyan students exiled in Cairo wrote in 1960 that history has passed its sentence on colonialism, imperialism and settlerism ... We, the African people of Kenya nay Africa - are now the executors of the sentence passed by history now! ${ }^{41}$ As Adom Getachew has

\footnotetext{
${ }^{36} \mathrm{P}$. Cullen, "Playing Cold War politics": the Cold War in Anglo-Kenyan relations in the 1960s', Cold War History, 18:1 (2018), 37-54; P. K. Kurgat, 'The shield and the sickle: Kenya-Russia relations since 1963', in K. Cheluget (ed.), Kenya's 50 Years of Diplomatic Engagement from Kenyatta to Kenyatta (Nairobi, 2018), 103-10.

${ }^{37}$ D. Branch, 'Political traffic: Kenyan students in eastern and central Europe, 1958-69', Journal of Contemporary History, 53:4 (2018), 811-31; E. Burton, 'Decolonization, the Cold War, and Africans' routes to higher education overseas, 1957-65', Journal of Global History, 15 (2020), 169-91; P. K. Kurgat, 'Education as a foreign policy tool: Kenyan students airlift to the Union of Soviet Socialist Republics and Eastern Europe, 1954-1991' (unpublished PhD thesis, Moi University, 2013); S. F. Onyango, 'Eastern socialist countries scholarships to Kenyans, Aeroflot and the Cold War conflict, 1959-1970' (unpublished MA thesis, University of Nairobi, 2016).

${ }^{38}$ Y. Richards, Maida Springer: Pan-Africanist and International Labor Leader (Pittsburgh, 2000); G. Horne, Mau Mau in Harlem? The U.S. and the Liberation of Kenya (Basingstoke, 2009); M. Dudziak, Exporting American Dreams: Thurgood Marshall's African Journey (Princeton, 2011); S. M. Markle, A Motorcycle on Hell Run: Tanzania, Black Power, and the Uncertain Future of Pan-Africanism, 1964-1974 (East Lansing, MI, 2017).

${ }^{39}$ Byrne, Mecca of Revolution; A. O'Malley, The Diplomacy of Decolonisation: America, Britain and the United Nations during the Congo Crisis 1960-1964 (Manchester, 2018).

${ }^{40} \mathrm{P}$. W. Otim, 'Local intellectuals: Lacito Okech and the production of knowledge in colonial Acholiland', History in Africa, 45 (2018), 275-305.

${ }^{41}$ Hoover Institute Archive, Tom Mboya papers, box 5, folder 1, Kenya Office Cairo to the editor, Daily Nation, 9 Aug. 1960, 3.
} 
shown, an appreciation of the importance of the international sphere to political thought and action during decolonisation may also, in turn, help us to better understand when and why the once seemingly possible came to appear impossible. ${ }^{42}$ Getachew's pan-African statesmen engaged with international institutions as 'worldmakers rather than solely nation builders' - or, we might add, rather than solely monarchists, majimboists, irredentists, or autochthons.

Debates about East Africa's future during decolonisation were not neatly bounded by nation, state, or indeed by region, but were deeply entangled with Afro-Asian solidarity, pan-Africanism, world civil rights struggles, and liberal and communist internationalisms - each of which had its own internal tensions. ${ }^{43}$ The worlds that East Africans imagined at the time of independence were many and contradictory. The Afro-Asian world was brought into homes through Radio Cairo and African students returning from India. ${ }^{44}$ North American trade unionists trained African workers in union organisation. ${ }^{45}$ East African cooperative workers trained in Israel. ${ }^{46}$ Gikuyu schoolchildren caught in the midst of the Mau Mau War hoped for rescue by American civil rights leaders or South African anti-apartheid campaigners. ${ }^{47}$ African youth leaders shaped the discussions of youth internationals in Copenhagen and Budapest. ${ }^{48}$ Goans in Nairobi joined the struggle for Lusophone African independence. ${ }^{49}$ Across the region, East Africans, whether or not they considered themselves 'global' citizens (and some certainly did), engaged sincerely with worldly practices and ideas that constitute our understanding of this period.

However, after independence many of the individual connections of this period, often sustained through letters and print, with varying degrees of state or international institutional sponsorship, systematically broke down, especially in social, cultural, and intellectual spheres. ${ }^{50}$ For Getachew, projects of political 'worldmaking', confronted with 'the kinds of states decolonization had created', ultimately 'culminated in projects that reinforced the nation-state' with all its 'majoritarian, homogenizing, and exclusionary tendencies' ${ }^{51}$ Yet deglobalising dynamics extended beyond the state as a player in international relations. These deglobalising dynamics did not develop in isolation from East African actors and events, in the diplomatic corridors of the UN and World Bank, but in interaction with them.

If we want to capture the multiple worlds imagined by East Africans in this period, we need to build on and take further recent scholarship which has combined the insights of area expertise with an attention to internationalisms, mobility, and print cultures. This will allow historians to explore how different types of connections, especially those outside of the sphere of trade and economics, were forged from East Africa. Crucially, it will also, in due course, allow us to account for how those connections suffered from, adapted to, or fed off the narrowing repertoires of political possibility in the 1960s and the global economic crisis of the 1970s.

\footnotetext{
${ }^{42}$ A. Getachew, Worldmaking after Empire: The Rise and Fall of Self-Determination (Princeton, NJ, 2019).

${ }^{43}$ S. L. Lewis and C. Stolte, 'Other Bandungs: Afro-Asian internationalisms in the early Cold War', Journal of World History, 30 (2019), 1-19; P. Hetherington and G. Sluga, 'Liberal and illiberal internationalisms', Journal of World History, 31 (2020), 1-9.

${ }^{44}$ J. R. Brennan, 'Radio Cairo and the decolonization of East Africa, 1953-64', in Lee, Making a World after Empire, 17396; G. McCann, 'Where was the Afro in Afro-Asian solidarity? Africa's "Bandung moment" in 1950s Asia', Journal of World History, 30:1-2 (2019), 89-123.

${ }^{45} \mathrm{P}$. T. Zeleza, 'Trade union imperialism: American labour, the ICFTU and the Kenyan labour movement', University of the West Indies, Social and Economic Studies, 36 (1987), 145-70.

${ }^{46}$ Kenyan National Archives (KNA) ACS/15/144, L. Ngureti, Embu Coffee Co-Operative Union to Commissioner of Co-Operative Development and Israeli Consulate, 3 Sept. 1962.

${ }^{47}$ N. Thiong'o, Dreams in a Time of War: A Childhood Memoir (London, 2010), 194.

${ }^{48}$ Archives of Makerere University, Kampala, AR/MAK/159/7, The Undergraduate, 1:7 (1955), 1.

${ }^{49}$ S. Durrani (ed.), Pio Gama Pinto: Kenya's Unsung Martyr, 1927-65 (Nairobi, 2018).

${ }^{50}$ L. Schler and U. Engel, 'Introduction: the momentous 1960s - reflections on an African decade', Comparativ, 29:4 (2019), 12.

${ }^{51}$ Getachew, Worldmaking, 177-81.
} 


\section{Part II: Global lives}

One way of exploring this moment, we argue, is through the life histories of individuals whose work and thought constituted the cross-border connections in which we are interested. Miles Ogborn refers to 'global lives', which we find helpful in drawing our attention to 'the ongoing organisation of different and partial relationships, networks and webs'. As Ogborn has shown, the use of life-writing as historiographical tool enables us to identify some of 'the variety of lives through which multiple worlds can be told'. ${ }^{52}$ The instructiveness of these 'global lives' does not depend on each individual having moved across East Africa or the globe - or indeed on them having understood their lives through such categories. Rather, the ensemble of practices they pursued enables the recovery of lives that fell entirely or partly outside a linear story of modernization and nation-building', in Jean Allman's words, and thus of stories of other ways that these same individuals perceived and engaged with the dynamics and possibilities of the twentieth-century world. ${ }^{53}$ James Brennan's use of the 'lives' of Nyasa-Tanzanian Dennis Phombeah to rewrite the history of international intelligence-gathering provides a fruitful model of such an approach to the decolonisation era. ${ }^{54}$ Taking three different themes Afro-Asian and pan-African internationalism, trade unionism, and literary culture - we suggest what this approach reveals about the shifting nature of global connections and their utility for narrating East Africa's decolonising moment.

\section{Afro-Asian and pan-African internationalisms}

In December 1958, Bibi Titi Mohamed, a leading voice in Julius Nyerere's Tanganyika African National Union (TANU), left Tanganyika for the first time to attend the All India Women's Conference at Kanpur. A recent reappraisal of Bibi Titi argues that the trip was not a 'defining moment' in her political thinking. ${ }^{55}$ Indeed, when Bibi Titi's life history was recovered through interviews in the 1980s and 1990s, historians were interested to reinsert women like her into the 'metanarrative' of nationalist organising in Tanganyika, from which they had been eclipsed. ${ }^{56}$ Thus, the importance (or irrelevance) of Bibi Titi's India trip was the potential for it to influence her activism on her return. However, if our driving interest is in the nature and variation of global connections, rather than of women's or nationalist mobilisation, we might ask different questions and turn to different types of sources.

For example, the African Students Association in India, largely comprising East African students on Indian government scholarships, wrote to Nyerere after hearing about Bibi Titi's trip to India. ${ }^{57}$ They hoped to send a copy of a book on Indian nationalism to TANU, via Bibi Titi. Viewed through this letter, her trip to India in the late 1950s maintained connections between a body of students, who were operating through older colonial connections revived (thanks in part to Nehru's foreign policy) in a pan-African and Afro-Asian sphere, and political leaders at home. We have a growing understanding of the experiences of such students, but the letter about Bibi Titi reminds us that 'students abroad' were not a separate story: they must be integrated into a fuller understanding

\footnotetext{
${ }^{52}$ M. Ogborn, Global Lives: Britain and the World 1550-1800 (Cambridge, 2008), 8-9.

${ }^{53} \mathrm{~J}$. Allman, 'Phantoms of the archive: Kwame Nkrumah, a Nazi pilot named Hanna, and the contingencies of postcolonial history-writing', The American Historical Review, 118:1 (2013), 120.

${ }^{54}$ J. R. Brennan, 'The secret lives of Dennis Phombeah: decolonization, the Cold War, and African political intelligence, 1953-1974', The International History Review, 43:1 (2021), 153-69.

${ }^{55}$ C. Chachage and J. Mgumia, 'Bibi Titi Mohamed', Oxford Research Encyclopedia of African History (2020), https://doi.org/10.1093/acrefore/9780190277734.013.473.

${ }^{56}$ S. Geiger, TANU Women: Gender and Culture in the Making of Tanganyikan Nationalism, 1955-1965, (Oxford, 1997), 164. See also R. Meena and A.-R. Mtengeti-Migiro, Wanawake Katika Siasa na Uongozi Tanzania (Dar es Salaam, 1988).

${ }^{57}$ Archives of the Chama Cha Mapinduzi (CCM), Dodoma, box 43, file 218, African Students Association to J. Nyerere, 15 Jan. 1959.
} 
of the changing roles of educational connections across independence. ${ }^{58}$ Bibi Titi herself, even with her travel limited by external sponsorship and TANU fundraising, became a means for literature to enter late colonial East Africa, where the list of proscribed publications was growing. ${ }^{59}$ Her mobility allowed East Africans to engage with politics in newly independent countries without physically travelling. Immediately after independence, such a role, and thus this particular type of connection, was less urgent.

Simultaneously, the significance of such sojourns overflows the category of anticolonial mobilisation and the cutoff point of independence. In Kanpur, Bibi Titi spoke about the paucity of scholarships to study abroad available in Tanganyika and how this disproportionately affected girls. ${ }^{60}$ She did not describe in interviews the conversations that her speech provoked with other delegates - presumably, these did not seem salient to the category of women's mobilisation on which she drew to narrate her life. Yet these sorts of conversations are part of the prehistory of international developmental discourses, accounts of which continue to obscure the diversity of their participants, which included Muslim women like Bibi Titi. ${ }^{61}$ These developmental discourses appeared to reach a peak of intensity, in terms of international organisations and conferences, in the 1960s, just when Bibi Titi more or less disappeared from public political life. Her political career, and any lasting connections she might have made with Kanpur delegates, were victim to personal-political conflicts surrounding the prescriptions of the 1967 Arusha Declaration. ${ }^{62}$ This deglobalising dynamic coincided with growing educational links for Tanzanians in the 1960s, a lag of sorts in the connections that Bibi Titi had called for in the 1950s. ${ }^{63}$

This overarching chronology - from 1950s internationalist conferences to 1960s incarceration - was not uniform, a fact illustrated with the story of one of Bibi Titi's contemporaries, Ugandan economist and political philosopher Boloki Chango Machyo W'Obanda. Machyo was abroad during the second half of the 1950s, when East African anticolonial campaigns intensified. He was invited to the United States in 1956 by Moral Re-Armament (MRA), a pan-denominational evangelical movement preaching individual moral reform as the alternative to anticolonial and Cold War violence. MRA was global in reach, prominent in Japan, Australia, Morocco, and India during this period, yet socially conservative in its internationalist and multiracialist vision. ${ }^{64}$

Studying in London, Machyo took part in student activism through the Uganda Association and the Budapest-based World Federation of Democratic Youth (WFDY) but remained marginal to Ugandan party politics during the period when the question of Buganda's position in Uganda dominated debate. Yet this 'colonial metropole' trajectory obscures much broader intellectual links Machyo made beyond the Anglophone world: even from London he published in the Samia language as well as English, engaged with Francophone thinkers like Sékou Touré, and built contacts with fellow East African Marxists writing in Swahili, such as Zanzibari Abdul Mohamed Babu. ${ }^{65}$ This is a prime example of how print cultures specific to the period - in this case cheaply produced pamphlets - allowed exchange of ideas in a pan-African, multilingual, leftist sphere.

\footnotetext{
${ }^{58}$ G. McCann, 'The trumpets and travails of "south-south cooperation": African students in India since the 1940s', in K. King and M. Venkatachalam (eds.), India's Development Diplomacy and Soft Power in Africa (Oxford, 2021); Milford, 'Harnessing the wind', 69-101.

${ }^{59}$ For example, on the banning of publications from Cairo in Uganda, see The National Archives of the UK (TNA) FCO 141/18247, 'Extract from the Uganda monthly intelligence report, October 1958'.

${ }^{60}$ Proceedings of the All India Women's Conference, 28th session, Kanpur, 27-31 December 1958.

${ }^{61} \mathrm{P}$. Lal, 'Decolonization and the gendered politics of developmental labor in southeastern Africa', in S. J. Macekura and E. Manela (eds.), The Development Century: A Global History (Cambridge, 2018).

${ }^{62}$ Chachage and Mgumia, 'Bibi Titi Mohamed'.

${ }^{63}$ E. Burton, 'Journeys of education and struggle: African mobility in times of decolonization and the Cold War', Stichproben - Vienna Journal of African Studies, 18:34 (2018), 1-17.

${ }^{64} \mathrm{R}$. Hofmann, 'The conservative imaginary: Moral Re-Armament and the internationalism of the Japanese right, 19451962', Japan Forum, 33:1 (2021), 77-102.

${ }^{65}$ B. C. Machyo, Sulwe (London, 1961); Machyo, Africa in World Trade (London, 1964).
} 
Unlike many of the anticolonial thinkers of the early 1960s, Machyo's later life saw him move towards public politics rather than being excluded from it, assuming (after a period of persecution under Idi Amin) a prominent role in Yoweri Museveni's National Resistance Movement and benefitting from state-sponsored trips to, for example, North Korea. Some of Machyo's early writing, such as his 1964 critique of how UN structures favoured wealthy nations, found a political stage of sorts, yet Machyo is absent in intellectual histories of Ugandan decolonisation, written largely through the lens of its kingdoms. ${ }^{66}$

From an East African perspective, there was nothing predictable about the fate of these various connections as the 1970s approached: Afro-Asian conferences discussing socioeconomic policy, like the one Bibi Titi attended, became far less frequent; thinkers on the left, like Machyo, rejected the conservative internationalism of MRA, even while the latter showed its films across the region with state support; as the WFDY pursued its anti-imperial agenda, East African youth group members struggled to maintain their independence from the state.

\section{Trade unionism}

Another 'global life' is the Kenyan trade unionist Hilda Otieno, a fleeting figure in the 'shadow archive' of decolonising East Africa. ${ }^{67}$ Our knowledge of her life is limited to the period between 1961 and 1963. At the time, Otieno was the assistant director of education within the Kenya Federation of Labour (KFL), the umbrella organisation for trade unions led by Tom Mboya.

The labour movement was the primary arena in which grassroots political participants across East Africa engaged with global forces during decolonisation. Through Tom Mboya, the KFL was connected deeply to the global and Cold War politics of the international trade union movement. In line with Mboya's stance, the KFL was affiliated to the International Confederation of Free Trade Unions (ICFTU), the international, stridently anticommunist labour organisation which included the American Federation of Labor and Congress of Industrial Organizations (AFL-CIO) and the British Trade Union Congress (TUC) among its affiliates. Under Mboya, affiliation to the ICFTU led to considerable funds flowing into the KFL's coffers. ${ }^{68}$

The influence of the ICFTU and the AFL-CIO were, in fact, felt far more deeply than simply at an elite level. For Hilda Otieno, external funding was of great practical significance. AFL-CIO funds supported Otieno's effort to provide education and training to women in the Kenyan workforce and the wives of male members of individual trade unions. Otieno's programme began in April 1961, from when she organised and delivered the training sessions single-handedly for over a year. ${ }^{69}$ Funded by both the ICFTU and AFL-CIO, Otieno taught her students home economics as well as English language and literacy classes. ${ }^{70}$

Boosted by her grant from the AFL-CIO, in 1962 Otieno joined in the great movement of East Africans in this period. Otieno's travels took her to West Germany and Israel. She spent over two weeks in the Federal Republic visiting various women's organisations. ${ }^{71}$ Her stay in Israel lasted six months, most of which was spent studying trade union organisation alongside women from across Africa and Asia. ${ }^{72}$ West Germany and Israel were much more than proxies for American interests. Both countries paid keen attention to the course of decolonisation across Africa; the plethora of new

\footnotetext{
${ }^{66}$ Machyo, Africa in World Trade.

${ }^{67}$ Allman, 'Phantoms'.

${ }^{68}$ A. Clayton and D. Savage, Government and Labour in Kenya 1895-1963 (Abingdon, 2016), 432-56; D. Goldsworthy, Tom Mboya: The Man Kenya Wanted to Forget (Nairobi, 1982), 149-65; Zeleza, 'Trade union imperialism'.

${ }^{69}$ IISH ICFTU 4482, International Solidarity Fund Committee, 'Kenya: Women's Activities', 6 July 1962.

${ }^{70}$ University of Maryland (UMD), George Meany Memorial Archive, AFL-CIO papers (AFL-CIO), Record Group (RG)

18-1, series 3, sub-series 1, box 10, folder 20, H. Otieno to M. Springer, 11 Aug. 1961.

${ }^{71}$ UMD AFL-CIO 18-1/3/1/10/19, H. Otieno to M. Springer, 16 Oct. 1962.

${ }^{72}$ UMD AFL-CIO 18-1/3/1/10/19, H. Otieno to M. Springer, 17 May 1962.
} 
states provided opportunities to both German states and Israel to win the support of independent nation-states in their respective struggles for diplomatic recognition and alliances. ${ }^{73}$

Otieno's global life reminds us of the multiplicity of internationalisms at play in the era of decolonisation. But her story tells us how that range of international connections tapered quickly in the years that followed. Within a decade after Kenyan independence, Otieno's world had apparently crumbled. As the networks in which she participated disappeared, so did Otieno from the 'shadow archive'.

The changes were partly exogenous. First, American interests in the Kenyan trade union movement cooled almost immediately after independence. The United States' government was determined to shore up relations with Jomo Kenyatta and so halted funding provided to Mboya and his allies by the American labour movement. ${ }^{74}$ But this money was also vital to Otieno's education project. Second, a decade later, Kenya severed diplomatic ties with Israel in response to the Yom Kippur War.

However, Otieno's global networks were dissolved as much by domestic politics as changes to the wider world. Her mobility and international sources of funds fell afoul of efforts by the Kenyatta government to exert greater control over the trade unions at home, for fear of their use as a political base by either Mboya or his rival on the left, Oginga Odinga. ${ }^{75}$ With the KFL replaced with a new, government-controlled Central Organisation of Trade Unions, the links between Kenyan trade unions and other international bodies were subject to strict state control. ${ }^{76}$ The mobility, the flows of finances, and the sense of common struggle that had characterised Otieno's engagement with the international trade union movement in the early 1960s - and which led to her presence in the archival record - were impossible to maintain.

In time, Kenyans forged connections with new forms of global politics in their efforts to reform and topple authoritarian rule. Indeed, Otieno's legacy lived on amidst a very different form of global politics than that in which she engaged in the early 1960s. She used her ICFTU connections to help finance the Kenya African Women's seminar at Limuru in $1963 .^{77}$ The seminar produced few immediate results but helped lay the foundation for new types of political engagement by Kenyan women in the decades to come. The global politics of anticolonialism and the Cold War may have been pushed to one side in the 1960s, but new transnational politics centred on issues of the environment and social justice eventually emerged to take their place. ${ }^{78}$ Specifically, the seminar helped forge new relationships between prominent Kenyan women and American counterparts, most notably Margaret ('Peggy') Snyder. The network formed at Limuru was of critical importance to was Snyder's role twenty years later in supporting the establishment of the Green Belt Movement, led by Nobel laurate Wangari Maathai. ${ }^{79}$

\section{Literary culture}

The shadows of the Cold War are also routinely cast over our final East African global life, that of Rajat Neogy. His tragic demise signalled the fragility of transnational cultural connections in the 1960s and the potency of dominant ruling elites in asserting their own competing political and economic internationalisms.

Born in Kampala to an immigrant Bengali family, in November 1961, at just 22 years of age, Neogy founded Transition, the boldest literary magazine of Africa's 1960s. It ran for 50 issues:

\footnotetext{
${ }^{73}$ For West and East Germany, see Roberts, 'Politics', 87-112; for Israel, see Z. Levey, 'Israel's entry to Africa, 1956-61', Diplomacy and Statecraft, 12:3 (2001), 87-114.

${ }^{74}$ W. Attwood, The Reds and the Blacks: A Personal Adventure (New York, 1967), 241.

${ }^{75}$ R. Sandbrook, 'Patrons, clients, and unions: the labour movement and political conflict in Kenya', Journal of Commonwealth Political Studies, 10:1 (1972), 3-27.

${ }^{76}$ Republic of Kenya, The Policy on Trade Union Organization in Kenya (Nairobi, 1965).

${ }^{77}$ UMD AFL-CIO 18-1/3/1/10/19, H. Otieno to M. Springer, 8 Nov. 1962.

${ }^{78} \mathrm{~W}$. Kanyi, 'Kenyan women's journey in their quest for affirmative action' (Nairobi, 2016), 3.

${ }^{79}$ W. Maathai, Unbowed: One Woman's Story (London, 2008), 169.
} 
37 published from Kampala (1961-8) and 13 from Accra (1971-4). At its height, 12,000 copies were printed quarterly; half consumed across Africa and half overseas, particularly in Britain and the US in recognition of the international Anglophone networks in which Neogy flourished.

Transition would become a focal point for emerging East African creative writing and political commentary. Neogy, as editor, placed young writers honing their craft in vibrant East African university journals like Penpoint (Makerere) or Nexus (Nairobi) - Ngũgĩ was published, as a Makerere student, in Transition - alongside established European and American allies such as Gerald Moore and Martin Luther King Jr. Transition's contributors comprised a who's who of pan-African creative talent - from Langston Hughes and James Baldwin to J. P. Clark, Okot p'Bitek, and Wole Soyinka.

The success of Transition rested on Neogy's personal relationships built in Kampala and across the world. In 1962, on the recommendation of Seth Spaulding of the US Office of Education, who had served on a UNESCO mission in Kampala, Neogy asked the prominent American poet James Laughlin to finance Transition through Laughlin's experimental New Directions press to 'find and encourage East African writing. . . [and] also to provide a link to international cultural streams, to widen perspectives and exchange ideas and not get stuck in an East African community alone'. ${ }^{80}$

Neogy finally secured funds through the South African writer Ezekiel (later Es'kia) Mphahlele, who, in 1961, became Africa Director of the Paris-based Congress for Cultural Freedom (CCF), a Euro-American institution founded in 1950 to combat the cultural influence of the Soviet Union. Mphahlele, who had worked at the CCF-sponsored Mbari Cultural Centre in Nigeria and became founding director of Kenya's partially CCF-funded Chemchemi Cultural Centre, worked closely with Neogy to develop East African artistic capacity.

Neogy's close friend in Kampala, the American writer Paul Theroux, proclaimed that 'Transition was more than a magazine; it was a movement, a vehicle for change . . global, risk-taking, abrasive', driven by Neogy 'flying by the seat of his pants'. ${ }^{81}$ Its literary contributors 'repurposed modernist versions of aesthetic autonomy' to forge freedom from colonial institutions and, increasingly, from authoritarian postcolonial states. ${ }^{82}$ But Neogy failed spectacularly. In 1968, he was incarcerated for sedition by President Milton Obote after publishing two articles by the opposition MP, Abu Mayanja, which lambasted the repressive turn of Uganda's government.

At a sensational trial, prosecutors stressed the neocolonial threat underpinning Transition. In 1967, a global exposé revealed covert CIA support for the CCF much to the consternation of Neogy, who denied knowledge of the link. ${ }^{83}$ Obote decreed Neogy a foreign agent after the discovery of a Swiss bank account in the name of Neogy's wife Barbara. ${ }^{84}$ At the trial, it also emerged that Neogy had not officially renounced his UK citizenship, acquired by his Indian descent under the 1948 British Nationality Act, due to an oversight. British officials noted Obote's emotional 'morbid preoccupation' with the case when he publicly castigated Transition as 'manned by non-Ugandan interests and citizens' and during a gruelling seven-hour private meeting with Barbara Neogy about Rajat's future. ${ }^{85}$ In February 1969, the chief magistrate rejected the prosecution's assertion that Mayanja's intervention had 'a subversive effect on the mass of the Ugandan population', and

\footnotetext{
${ }^{80}$ Wole Soyinka Papers, Harvard University, MS Am 2077 (1839), Africa Correspondence, folder 1, R. Neogy to J. Laughlin, 18 Feb. 1962.

${ }^{81} \mathrm{P}$. Theroux, 'More than a magazine', Transition, 106 (2011), 12-19.

${ }^{82}$ P. Kalliney, 'Modernism, African literature and the Cold War', Modern Language Quarterly, 76:3 (2015), 33; S. Gikandi, 'Modernism in the world', Modernism/Modernity, 13:3 (2006), 419-24.

${ }^{83}$ Interview, 'Rajat Neogy on the CIA', Sunday Nation (Nairobi), 11 June 1967.

${ }^{84}$ International Association of Culture Freedom (IACF) Archive, University of Chicago, box 384b, B. Neogy to S. Stone, 27 Oct. 1968.

${ }^{85}$ 'The President's open letter', Uganda Argus, 23 Jan. 1969; TNA FCO 31/491, W. Wenban-Smith, British High Commission, Kampala to East African Department, Foreign and Commonwealth Office, 13 Mar. 1969; E. Le Tocq, East African Department, Foreign and Commonwealth Office confidential memorandum, 25 Mar. 1969.
} 
Obote eventually released a brutalised Neogy from Luzira prison. ${ }^{86}$ CCF relationships proved critical to Neogy's defence, notably through family friend and CCF officer David Goldstein, who liaised with Amnesty International to secure a legal team. ${ }^{87}$

Cold War structures of cultural sponsorship and gatekeeping cannot be dismissed. A 'Cold War paradigm' of finance, publishing regimes, marketing, institutional awards and canonisation in African literature helped influence who could be heard and who could not over the latter half of the twentieth century and into the twenty-first - a hawkish 'politics of visibility' that privileged particular western definitions of 'dissident' writers, in the words of Bhakti Shringarpure. How texts and authors entered the world clearly mattered in the 1960s and over the long term. ${ }^{88}$

However, to centre Cold War drama and stricture at the high-water mark of Transition's power in the mid-1960s cannot entirely capture the role of international cultural institutions in Neogy's world and their significance for East Africa. The CCF provided a material lifeline for Transition, but not its only one. CCF leaders never dictated Neogy's editorial stance and never greatly shaped Transition's notably brash and politicised content, despite subtle attempts to do so. Top CCF officials came to regard Neogy as a somewhat tricky partner, ignoring deep engagement with schemes of CCF outlet cross-promotion and repeatedly failing to balance his books. ${ }^{89}$

Above all, such international connection opened up pan-Africanist space for creative citizens to debate the pathways of postcolonial culture on their own terms. Transition worked closely with Mbari's Black Orpheus, as well as with the CCF-supported South African magazines The New African and The Classic. Africa's most anthologised poet, Christopher Okigbo, who met Neogy at the 1962 Makerere Writers' Conference, became Transition's West Africa correspondent. However, such community-building was not only about the participation of the subsequent big names of African literature. The importance of the worlds opened up by Neogy and his comrades was also concerned with the ways in which hundreds of forgotten young people - who once studied arts or wrote in East Africa's university publications but moved onto alternative careers engaged with the world through Transition or Mbari to conceive their own ideas about culture, freedom, and equality. It was about people like Hilda Rwabazaire, who sat on the editorial board of Makerere's Penpoint in 1968 to, like Neogy, give voice to those 'who feel restricted by traditional patterns of literary expression - who feel that what they have to say can be put differently, and must be put so. ${ }^{90}$ After university, Rwabazaire became a broadcast journalist in Uganda, followed by a 25-year career in the communications department of the United Nations Development Programme, a champion of women's empowerment and HIV/AIDS awareness across Uganda and the world in the 1990s.

Neogy's work was not a simple story of reinforcing comfortable pan-African cosmopolitanisms. Fissures formed between East Africa and West Africa around views on race and liberty. Mphahlele was outspoken against Negritude creating animosity with Présence africaine and his predecessor as CCF Africa Director, the African-American scholar and diplomat Mercer Cook. ${ }^{91}$ Neogy followed suit. In 1962 he declared,

\footnotetext{
${ }^{86}$ 'Acquittals in Uganda', The Times (London), 2 Feb. 1969.

${ }^{87}$ IACF, box 50, D. Goldstein to B. Neogy, 12 Dec. 1968.

${ }^{88}$ B. Shringarpure, Cold War Assemblages: Decolonization to Digital (New York, 2019), 136-8; 164-6; See also M. Popescu, At Penpoint: African Literatures, Postcolonial Studies, and the Cold War (Durham, NC, 2020).

${ }^{89}$ IACF, box 42, J. C. Hunt to Neogy, 14 Jan. 1964; John C. Hunt to Neogy, 3 Apr. 1964. IACF box 304, I. Kats to E. Mphahlele, 12 Feb. 1964; R. Farrand to I. Kats, 16 Nov. 1964.

${ }^{90}$ Editorial, Penpoint, 24 (1968), 1.

${ }^{91}$ M. Cook and E. Mphahlele 'The African personality - two views', The New Leader (New York), 24 Oct. 1960; G. Massé, 'Cold War and Black transnationalism: Aimé Césaire and Mercer Cook at the first International Congress of Black Writers and Artists', Palimpsest: A Journal on Women, Gender, and the Black International, 4:2 (2015), 115-34.
} 
I do not like to think of it [Transition] as a magazine which has even to think in terms of or be conscious of the racial composition of its contributors. . . Negritude as a concept I'm afraid cuts absolutely no ice in East Africa. ${ }^{92}$

His was a call for East African belonging alive to inclusion and the future rather than autochthony rooted in ethnic divisions solidified under colonial rule.

Internationally hyperconnected, Neogy's was a project also rooted in the local, in particular multicultural Kampala where he conversed in English, Swahili, and Hindi. In 1958, Neogy agitated for a nonracial public sphere and common roll through the Uganda Action Group alongside fellow young Ugandan Asian activists Gurdial Singh and Natoo Karia. Neogy liaised with Uganda National Congress leader Ignatius Musaazi but was frustratingly denied party membership on grounds of race. Equally, Neogy lamented that Asian elders could not see past communalism in thinking about the independent future. ${ }^{93}$ In 1959, he lauded a 'an intellectual breakaway from the feudalism of Asian thinking in Uganda in the past' through new print cultures 'not restricted on racial lines'. ${ }^{94}$

His 1966 editorial 'Do magazines culture?' took this further as he argued more floridly that interventions like Transition could drive forward an accommodative, dynamic East Africa to expunge the remnants of colonialism. He drew a dichotomy between 'do cultures' and 'don't cultures'. The latter were 'akin to frustrated spinsters in a family. They are censorious, opinionated, smug, complacent, and intent on preserving the "tradition". . . indicative of a dying out phase'. He celebrated East Africa's new 'do culture', which was 'permissive, experimental, vigorous and challenging'. The success of the 'do culture' depended on 'how hospitable it is to ideas from outside, and how freely it delves into itself as a result. ${ }^{95}$ Neogy's was a cry of the young, who grew up in the city and for whom ossified concepts of ethnicity did not have to be the grammar of a new East Africa. Transition was a window, carefully opened by Neogy, through which the world was presented jostling ideas about African decolonisation, while Neogy's connections drove one version of progressive change. ${ }^{96}$

Such conceptions of the 'do culture' were not shared by Uganda's leadership. This is not to suggest that Obote's castigation of Transition's foreignness sprang from the shunning of internationalism. As Transition was proscribed, Obote welcomed Tiny Rowland's Lohnro conglomerate, which bought the Standard Group newspapers in 1967 and gave favourable coverage of the government for profit. ${ }^{97}$ Obote's condemnations of Transition served as proxies for differing visions of Ugandan state and society - for example on the role of capital or ethnicity within nation building. They also revealed the multiplicity of competing internationalisms at play, with certain forms of cultural connection and literary output increasingly throttled by authoritarian states. In the 1970s, the repression of Idi Amin's regime compelled Ugandan poet Taban Lo Liyong - who studied at Howard University, was the first African graduate of the Iowa Writers' Workshop, and wrote provocatively in Transition in the mid-1960s - to find haven at the University of Nairobi over Makerere.

Neogy's world quickly crumbled. Traumatised by his incarceration and increasingly mentally ill, Neogy left Uganda for Ghana in 1971 in an abortive attempt to restart Transition with his friend Soyinka. ${ }^{98}$ Neogy finally emigrated to the US, 'where he ended his days in poverty . . very fragile,

\footnotetext{
${ }^{92}$ Interview with R. Neogy for African Writers Club (BBC radio), c. 1962, available at http://sounds.bl.uk/.

${ }^{93}$ E. Taylor, Asians and Africans in Ugandan Urban Life, 1959-1972 (unpublished PhD thesis, University of Michigan, 2016), 75-87; R. Gregory, Quest for Equality, 113.

94، Party seeks those who 'believe in Uganda', Uganda Argus, 13 Feb. 1959.

${ }^{95} \mathrm{R}$. Neogy, 'Do magazines culture?', Transition, 24 (1966).

${ }^{96}$ M. J. Echureo, 'From Transition to Transition', Research in African Literatures, 22:4 (1991), 138.

${ }^{97}$ S. Mawby, The End of Empire in Uganda: Decolonization and Institutional Conflict, 1945-79 (London, 2020 ), 120.

${ }^{98}$ IACF box 38, S. Stone to D. Goldstein, 9 Feb. 1972; B. Neogy to D. Goldstein, 21 Febr. 1972; Dr. D. Rosen to D. Goldstein, 13 Mar. 1972.
} 
dazed looking', lamented Theroux. ${ }^{99}$ Neogy died in San Francisco in 1995 four years after Transition was revived in the diaspora under Henry Louis Gates Jr. Published from the Hutchins Center for African and African-American Research at Harvard University, Transition remains a globally significant forum for pan-African intellectual and cultural debate, one of Neogy's durable legacies. ${ }^{100}$ Neogy's short career underlined the significance of internationalist cultural networking in building stages on which young Africans debated the nature of postcolonialism and the methods of its attainment on their own terms in the 1960s. It also exposed the brittleness of these connections. His demise in exile embodied the disappointments and fractures that followed.

These glimpses of global lives that inhabited worlds of Afro-Asian and pan-African internationalisms, trade unionism, and the sphere of literary culture allow us to start thinking differently about the globalising and deglobalising dynamics that characterised the 1940s to the 1970s. Viewing the connections that these individuals forged from an explicitly regional perspective, rather than through the lens of the themes that have driven recent histories of decolonisation in Kenya, Uganda, and Tanzania, confirms that East Africans did indeed participate in the early Cold War 'Bandung moment' in ways that were specific to the region's longer histories of labour, migration, education, and religion. More importantly, asking what happened to these lives, collectively, suggests how much we are missing by thinking about the end of this period primarily in terms of global economic crisis and the state. Individual lives do not obscure structural factors but rather reveal patterns about why these factors mattered.

\section{Part III: Conclusion}

In the era of decolonisation, when East Africa's global future was contingent and uncertain, competing visions of modernity, global citizenship, and African autochthony battled for ascendancy. But increasingly, connections were broken and vistas narrowed. By the late 1970s, Afro-Asian solidarity had faded into obsolescence, Kenyan trade unionism was neutered as a mass political movement, and Transition was in abeyance. Exploring global lives in this era tells us that global connections are fragile, that they exist unevenly across and between national contexts, and that they can disintegrate, even in very short periods of time. Not only do individual lives challenge assumptions of the linearity of globalisation, they help account for the unexpected ways that deglobalising dynamics emerged.

It is this fragility, retrenchment, and uneven distribution of global connections that makes an attention to such connections important, both for historians of East Africa and for global historians interested in other regions of the world. The very appeal of the wider world to East Africans in the era of decolonisation lay in the possibility of discovering alternative futures to those seemingly dictated by economic and political structures inherited from colonial rule. This was a space characterised by variation and connections across the East African region, and by plurality and competing visions, all of which are important to recover. But it is also important for historians to seek to account for the growing constraints which characterised what the historian Carolien Stolte has described as the 'more closed and fractured world' of the $1960 \mathrm{~s}^{101}$

The chronology of postcolonial Africa is dominated by discourses of development or governance which stress continuity from the colonial past into the postcolonial present. ${ }^{102}$ But approaching the

\footnotetext{
${ }^{99}$ Theroux, 'More than a magazine', 19.

${ }^{100}$ For a celebration of Neogy and his legacies, see 'Fifty years: Transition celebrates its storied history', Transition, 106 (2011). For a critical analysis of Transition's migration to the US and its 'diasporadic nomadism', see Echureo, 'From Transition to Transition', 135-45.

${ }^{101} \mathrm{C}$. Stolte, 'Introduction: trade union networks and the politics of expertise in an age of Afro-Asian solidarity', Journal of Social History, 53:2 (2019), 344.

${ }^{102}$ F. Cooper, 'Possibility and constraint: African independence in historical perspective', The Journal of African History, 49:2 (2008), 167-96; M. Mamdani, Citizen and Subject: Contemporary Africa and the Legacy of Late Colonialism (Princeton, 1996).
} 
period from the perspective we have outlined here suggests that we need to disrupt this emphasis on continuity and explore when and why one set of ideas and strategies won out over others. While this story must be understood in the context of the Cold War, global economic crisis, and the challenges of postcolonial state building, in East Africa, as elsewhere in the postcolonial world, it is not reducible to these dynamics. Putting East African histories into dialogue with global histories offers an important way forward in this endeavour.

At independence, East Africa was as favourable an environment for an embrace of the wider world as any region more commonly included in the canon of global studies, such as South and Southeast Asia or the Caribbean. But within just twenty years, many of the global connections built in this period were broken. This makes the retrenchment of global connections all the more dramatic and the poignancy of the East African case instructive for all interested in the study of the making and unmaking of worlds.

Acknowledgments. This article is supported by the Leverhulme Trust, through the grant RPG-2018-241 'Another World? East Africa and the Global 1960s'. The authors would like to thank project members Anna Adima and Daniel Heathcote, as well as the project's Advisory Board, and participants of project workshops in Nairobi, Edinburgh, and online. Thank you especially to Tom Cunningham for comments on an earlier draft, and to anonymous reviewers for critical and detailed reports that significantly improved the article.

Cite this article: Milford I, McCann G, Hunter E, Branch D (2021). Another World? East Africa, Decolonisation, and the Global History of the Mid-Twentieth Century. The Journal of African History 62(3), 394-410. https://doi.org/10.1017/ S0021853721000566 